\title{
Modeling the Hydrological Characteristics of Hangar Watershed, Ethiopia
}

\author{
Abdata Galata ${ }^{1}$ \\ ${ }^{1}$ Jimma University Institute of Technology
}

December 12, 2020

\begin{abstract}
Modelling the hydrological characteristics of watershed is a method of understanding behavior and simulating the water balance components of watershed for planning and development of integrated water resources management. The soil and water assessment tool (SWAT) physically based hydrological modelling was used for modelling hydrologic characteristics of the Hangar watershed. The data used for this study were digital elevation model (DEM), land use land cover data, soil map, climatological and hydrological data. The model calibrated and validated using measured streamflow data of 13 years (1990-2002) and 9 years (2003-2011) respectively including warm-up period. The SWAT model performs well for both calibration $(\mathrm{R} 2=0.87$, NSE $=$ 0.82 and PBIAS $=+1.4)$ and validation $(\mathrm{R} 2=0.89, \mathrm{NSE}=0.88$ and PBIAS $=+1.2)$. The sensitivity analysis, which was carried out using 18 SWAT parameters, identified the 13 most sensitive parameters controlling the output variable and with which goodness-of-fit was reached. The analysis results indicated that the watershed receives around, $9.6 \%, 59.9 \%$, and $30.5 \%$ precipitation during dry, wet and short rainy seasons respectively. The received precipitation was lost by $9.6 \%, 40.5 \%$, and $41.3 \%$ in the form of evapotranspiration for each seasons correspondingly. The surface runoff contribution to the Watershed were $3.8 \%$, and $79.2 \%$ during dry and wet seasons respectively, whereas, it contributes by $17.0 \%$ during short rainy seasons.
\end{abstract}

\section{Hosted file}

Modelling Hydrological Characteristics.pdf available at https://authorea.com/users/351805/ articles/498427-modeling-the-hydrological-characteristics-of-hangar-watershed-ethiopia

\section{Hosted file}

Figure 1.pdf available at https://authorea.com/users/351805/articles/498427-modeling-thehydrological-characteristics-of-hangar-watershed-ethiopia

\section{Hosted file}

Figure 2.pdf available at https://authorea.com/users/351805/articles/498427-modeling-thehydrological-characteristics-of-hangar-watershed-ethiopia

\section{Hosted file}

Figure 3.pdf available at https://authorea.com/users/351805/articles/498427-modeling-thehydrological-characteristics-of-hangar-watershed-ethiopia

\section{Hosted file}

Figure 4.pdf available at https://authorea.com/users/351805/articles/498427-modeling-thehydrological-characteristics-of-hangar-watershed-ethiopia

\section{Hosted file}


Figure 5.pdf available at https://authorea.com/users/351805/articles/498427-modeling-thehydrological-characteristics-of-hangar-watershed-ethiopia

\section{Hosted file}

Figure 6.pdf available at https://authorea.com/users/351805/articles/498427-modeling-thehydrological-characteristics-of-hangar-watershed-ethiopia

\section{Hosted file}

Figure 7.pdf available at https://authorea.com/users/351805/articles/498427-modeling-thehydrological-characteristics-of-hangar-watershed-ethiopia

\section{Hosted file}

Table 1.pdf available at https://authorea.com/users/351805/articles/498427-modeling-thehydrological-characteristics-of-hangar-watershed-ethiopia

\section{Hosted file}

Table 2.pdf available at https://authorea.com/users/351805/articles/498427-modeling-thehydrological-characteristics-of-hangar-watershed-ethiopia

\section{Hosted file}

Table 3.pdf available at https://authorea.com/users/351805/articles/498427-modeling-thehydrological-characteristics-of-hangar-watershed-ethiopia 